\title{
The debt trap of the Greek economy and the way out
}

\author{
Theodore Katsanevas ${ }^{1}$
}

\begin{abstract}
:
In this paper it is argued that, in an economy with heavy loans such as Greece, structural reforms are not enough to lead the country out of the crisis. Only a Grexit with deep cuts and restructuring of debts, together with efficient state management and development policies may lead to growth. Greece has fallen in a huge debt trap which is perpetually growing by new loans.
\end{abstract}

A little less than half of these loans have been created during the euro zone period and particularly after the 2008 crisis. In accordance with the Eurogroup agreements, Greece is obliged to pay every year to its lenders $15 \%$ of its GDP (27 billion euro) up to the year of 2023 and 20\% of its GDP (36 billion), between the years 2023 and 2060. No country in the world can survive under such a heavy burden of debt obligations. It is argued that, even a country with heavy loans such as Greece, can succeed growth by imposing structural reforms such as sweeping impediments of labour, goods and service markets, breaking business and union monopoly power, make it easy to fire unwanted employees, removing regulations, red tape and licensing fees, privatizing state assets, increasing taxes and suppressing pensions etc.

This is nothing but a totally false hypothesis. It has been illustrated in research that, structural reforms may provide in the long run a yearly growth of a little over 1\%. It is also found that, they do not increase output during a crisis and they might have negative effects in the medium run. Thus, in the case of Greece, only deep cuts and restructuring of the debt (as with the German debt in the London 1953 agreement), accompanied with Grexit, development policies, efficient state management and reasonable structural reforms, may lead to the way out of the crisis and to growth.

\footnotetext{
${ }^{1}$ Professor Emeritus University of Piraeus
} 


\section{Introduction}

During the post war period, Greece witnessed a satisfactory and even impressive economic development with years of high growth followed by short periods of stagnation, and ever since the mid-seventies, it has entered the club of the developed countries. Greece entered the European Union in 1980 and the euro zone in 2002 under a climate of euphoria, looking towards even better days. In the beginning of the euro years during 2002-2008, the country lived in a non-productive affluence - a false paradise with an enormous expansion of loans, both state and private. European banks, mainly German and French, where wide open to Greek state loans, most of which were directed to the purchase of imported goods from the same countries and for armament from the west. Private banks also where competing in offering the most attractive loan terms almost without any guarantee.

In fact, they were pushing people and businessmen to become their lenders. In 2008 the international crisis hit like a thunderstorm the country. Then under Berlin's guidelines, the euro zone imposed upon Greece extreme deflationary policies that created a vicious circle of deep recession. The lenders asked for their money back and since the debtor could not pay, they provided new loans. The country was trapped; the Modern Greek Tragedy had been born. (Rogoff, K. 2015; NegrepontiDelivani, M. 2014; Thalassinos et al., 2010; 2015; 2014; Thalassinos and Dafnos, 2015; Thalassinos and Stamatopoulos, 2015; Thalassinos, 2008; Thalassinos, 2014).

After its entrance in the euro zone instead of better days, the once affluent Greece became a poor relative of Europe and a beggar of new loans. The huge burden of the ever-increasing debts, the overvalued euro and restrictive economic policies, led the country to a vicious circle of recession with no end and hopes of inversion.

Despite, austerity measures and the haircut of 2011 (PSI)2, mainly financed by Greek pension funds, state and local organizations, Universities and private bondholders (Bevan, 2012), the enormous Greek debt continues to rise. From $€$ 303.5 billion or $157 \%$ of the GDP in 2012, it soared to $€ 323$ billion or about $180 \%$ of the GDP by the end 2016.

It is argued that the Greek debt has been inherited from the past because of bad and corrupt state management. Yes, part of the blame may be related to the malpractices of the Greek political system. But we must not forget that, the same political system,

\footnotetext{
${ }^{2}$ The euro zone authorities in their session of 21/8/2011, decided the implementation in Greece of the so-called Private Sector Involvement (P.S.I ), which implies payments for the public debt with inflows from the private sector (bonds belonging to Social Security and Public Organizations, Local Government, Universities,private bondholders etc). The term PSI has been firstly used for the restructuring of the public debts of Russia, Turkey, Argentina, Ecuador, Brazil.
} 
also to be found in many other countries, existed also in the past during the previous 150 years of the drachma years.

Histogram 1. Average Annual Growth of GDP in Greece, the GIPSI, the euro zone and the rest of the world

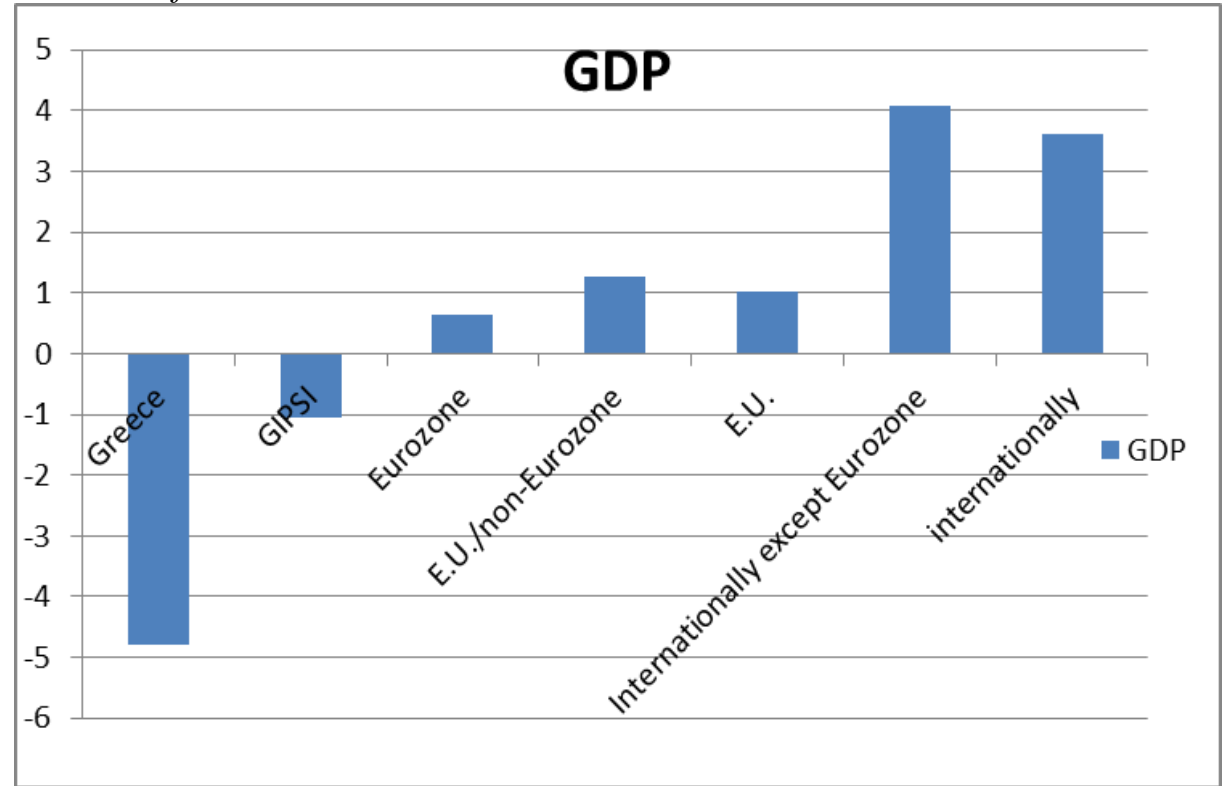

Source: World Bank, The Global Outlook, 2016. Own elaboration of analytical data of all countries internationally. Latvia and Lithuania have not been included in the above calculations as euro zone countries, because they entered in the euro area in 2014 and 2015 respectively. The so-called GIPSI are Greece, Italy, Portugal, Spain and Ireland.

Although there were several economic crises and bankruptcies in the country's economic history, (Deo et al., 2011), as in many other countries. None one remembers a deep and long catastrophe like the one witnessed today. Moreover, in the same declivity trend, although to a lesser extent, Greece is followed by Italy, Portugal, Spain, Ireland. (Weeks, 2013). But also, the whole euro zone is not doing well, crawling at the bottom of world economic development (Histogram I). Moreover, in accordance with Eurostat data, the debt as a percentage to the GDP was doubled in other peripheral countries between 2008-2015. Apart from Greece where it jumped from $120 \%$ to $181 \%$ of the GDP, in Ireland climbed from $47 \%$ to $89 \%$, in Portugal from $82 \%$ to $149 \%$, in Italy from $112 \%$ to 157 and in Cyprus from $55 \%$ to $110 \%$. Above all in Spain it was tripled since it rose from $47 \%$ to $117 \%$ of the GDP.

This widely spread saying that the Greek debt has been inherited from the past is a cunning myth. According to Eurostat data, the debt as a percentage of the GDP, has almost doubled after the 2008, during the euro zone years. (Histogram 2). In other words, the Greek debt created during the euro zone years, almost equals the total 
debts of the past 150 years (which have been going through cuts and restructuring, an arrangement not accepted within the euro).

\section{Histogram 2. Evolution of the Greek debt as a percentage of the GDP}

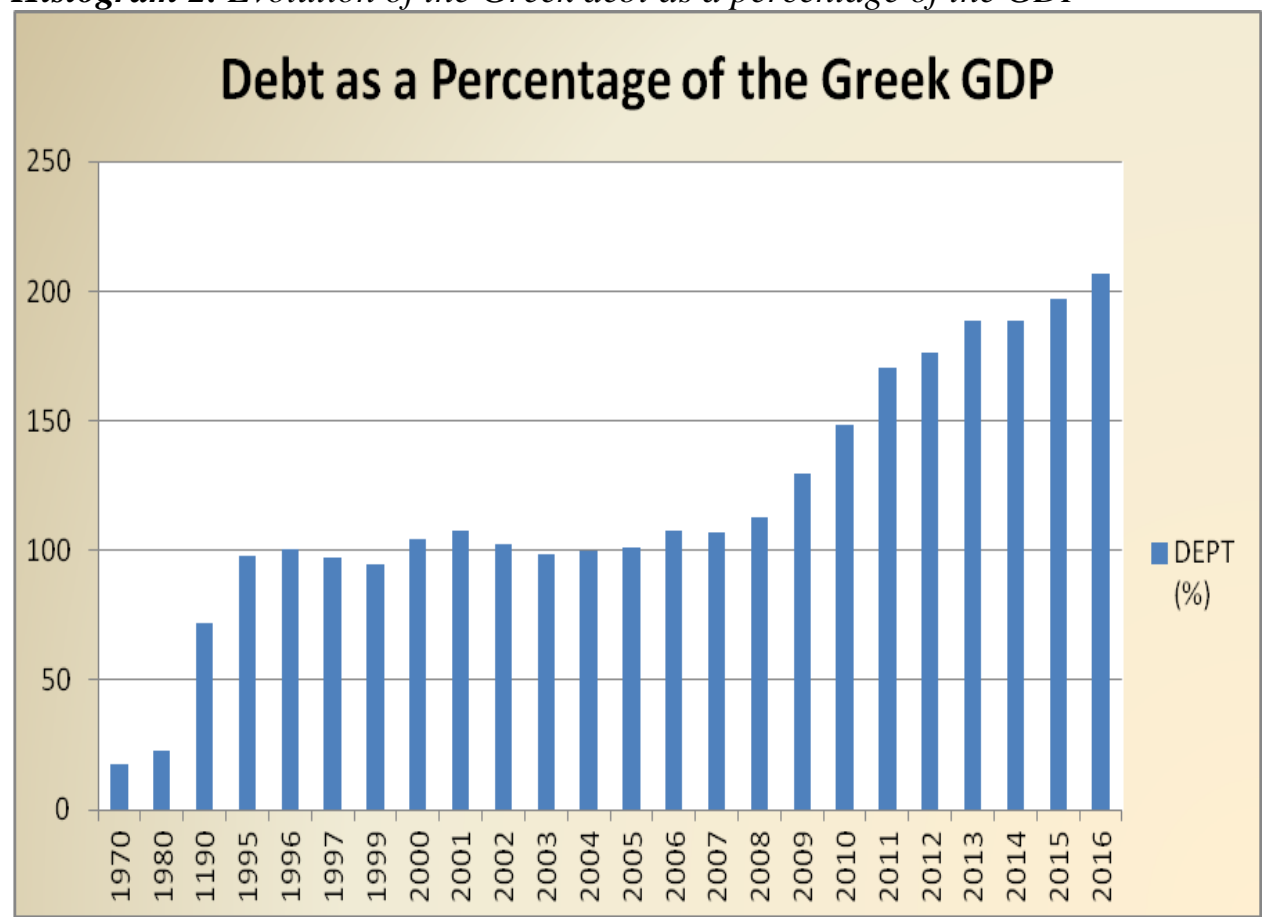

Source: Eurostat

There is also another important point. If the Greek debt was enormous as said before the year 2002, how could Greece be accepted in the euro zone where a main prerequisite for such an entrance is an acceptable level of debt less than 60-80\%?

The debt trap is destroying the Greek economy and keeps the country under an economic and political occupation. New loans are given to the Greek government to pay older loans and this has no end. In May 2016, the European School of Management and Technology (ESMT) based in Berlin, published a research report providing a descriptive analysis of where the Greek bailout money went since 2010 (Rocholl, A., Stahmer, A., ESMT, 2016). Out of the 220 billion euro disbursed to Greece since the beginning of the economic crisis about $95 \%$ (210,3 billion euro ) has gone mainly to German and French banks and less than 5\% (9.7 billion euro) went into the state budget for the benefit of Greek citizens (Histogram III). More analytically, apart from the above sum of 9,7 billion, 86.9 billion euro $(46,67 \%)$ of the bailout money went to repay old debts, 52.3 billion euro $(28,08 \%)$ for payment of interest, and 37.3 billion euro $(20,03 \%)$ for the recapitalization of Greek Banks. In the latter case, this was necessary because of the large escape of capital abroad - a fact also related to the malfunction of the euro zone. 
Histogram 3. Estimations for the distribution of euro loans to Greece before 2015

ESMT estimations about the distribution(\%) of loans to Greece

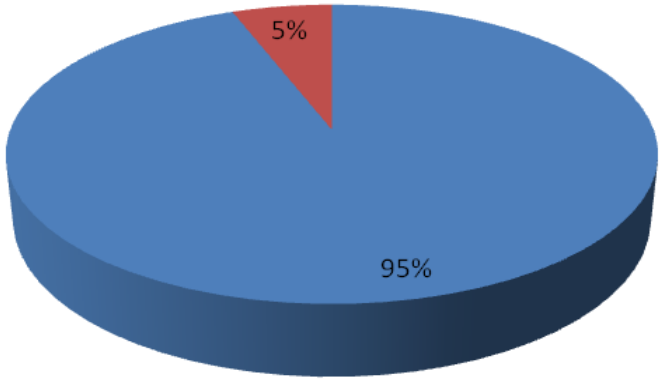

- German and French banks

- Greek state budget

Source: European School of Management and Technology, Berlin

These findings were assumed and discussed but few knew as a fact, yet now they are confirmed by the above verified study. As stated in the same study, "for six years there are attempts to stop the Greek crisis with tougher measures and loans that require new loans to pay back the older ones. The cause of the failure is less in the side of the Greek government and more in the design of assistance programs. These calculations are raising doubts about the proper design of assistance programs, since the loans serviced debts, although Greece is the 2010 de facto bankrupt. The salvation of Greek banks proved disastrous for taxpayers. Overall, they channelled 37.3 billion euro in Greek banks from the two aid packages. But the aid is fully diminished. After the recapitalization by the PSI of 2012 the banks have lost almost 98\% of their value in the stock market. Moreover, the resulting risk transfer from the private to the public sector and the subsequent risk transfer within the public sector from international organizations such as the ECB and the IMF to European rescue mechanisms such as the ESM, still constitute the most important challenge for the goal to achieve a sustainable fiscal situation in Greece" "3. After the agreement with the lenders in the summer of 2015, and the decisions of the two Eurogroups of July 2016 and June 2017, the debt trap became even bigger. After 2015, all new loans

\footnotetext{
${ }^{3}$ The ex-Prime Minister of Italy, Massimo D' Alema in a revealing interview to Skyptg in $6 / 8 / 2015$ pointed out that ". $€ 220$ bn out of the $€ 250 \mathrm{bn}$ of aid to Greece has gone directly to the German, French and Italian banks, as interest paid to the lenders. In reality, when we say that we 're paying the Greeks' pensions, that's not true - no, we're paying the German banks. It goes a roundabout way, yes, it does a little trip, but the Greeks don't even get a whiff of it. This mechanism cannot last for any length of time - it is not working and will not work".
} 
will be used to pay back older loans and there is much more burden to that as we will discuss further on.

\section{The economic deadlock}

The Greek GDP has fallen more than 25\% since 2008, and this dramatic drop has no parallel in length in history (Histogram IV). Moreover, the Greek households lost $40 \%$ of their wealth between 2009-2014. (Charalampakis, 2017). Greece has become a European champion in unemployment rising to unprecedented levels of $23 \%-25 \%$, and youth unemployment to approximately 62\%. As a result, more than 500.000 Greeks, most of them young, emigrated abroad in the last five years. All economic indicators (GDP, unemployment, investments, industrial production, construction, etc), move with a monotonous downward trend (The World Bank Factbook, 2016, IMF Economic Outlook, 2016, ELSTAT).

Inflation moves at a negative pace of $1-2 \%$ and this is extremely negative for growth and the burden of debts. Not only the public, but also private debts have increased dramatically. More than one in two businesses fails to service their loans, tax and insurance obligations. Overall arrears to the Greek Income Revenue Service (IRS) are growing sharply now surpass 215 billion by mid-2017, that is $120 \%$ of GDP. More than half of the total of 5.8 million taxpayers owe to the IRS. Many millions of debts are also owed to businessmen and pensioners by the State which always postpones its payments obligations to present a better budget. The only positive sign was the equilibrium and/or the surplus in the State budget and the balance of payments, mainly due to the deep drop of imported oil prices and large cuts in public expenditure, which turn leads to more recession.

\section{Histogram 4. Evolution on GDP (selected countries)}

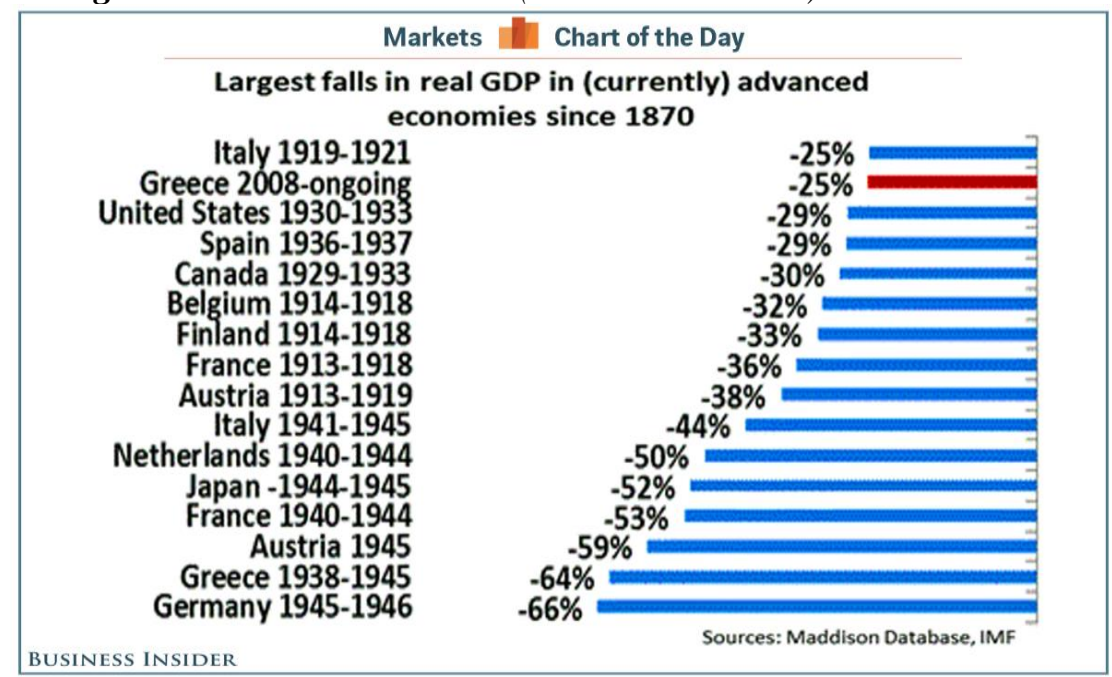


Continuously expanding is the number of uninsured citizens and entrepreneurs. The pension funds, wounded with the haircut of their reserves from the PSI in 2011, are sinking (Bevan 2012). Their deficits are growing sharply and this results to huge cuts in all kinds of pensions. The economy is drying up and contracting more. The extreme recession policies, the huge levels of unemployment, the excessive compression of labor rewards and of pensions, are both inhumane, and uneconomic. They lead to a large drop of domestic demand with dangerous economic and social consequences. Recession creates more recession lowers the business circle and the tax base. Poverty creates more poverty, misery, hate and upheaval. Loans lead to more loans and dependency - a perpetual cycle ${ }^{4}$. Mainly due to the overvalued euro, the lack of currency liquidity and the high interest rates of loans for business transactions, the country's poor competitiveness is dying. Recession cannot be beaten with more recessionary policies, an overvalued currency and without a generous development plan (Krugman, 2012). Over the long term, this is burdensome to all, even for Greece's lenders. These policies are totally wrong. They are not the outcome of logic. And common logic is what we need today

\section{The negative influence of the euro}

The overvalued euro is a costume that does not fit peripheral economies based on labor intensive economies. It mainly favours countries that create high technology and innovation products, those with capital and technology intensive economies. For instance, when a product such as a new effective medicine safeguards its patent and cannot be copied for at least 20 years, its production cost may be trivial, but its sale price is extremely high. This allows for an absurd profit margin, since the labor and raw materials cost is significantly low. A modern magnetic resonance tomograph for example, one made by Siemens, is so expensive because its purchase is considered necessary in the global market. This is true for its spare parts and maintenance as well. Conversely, Greece, even though its immense human-scientific potential has migrated abroad, maintains tourism and agriculture as its main production orientation which require a labor intensive production process. Therefore, a significant amount of workforce is needed but unable to reduce its cost below a certain point, so as the total production cost to be lower or equal to that of our competitors.

Moreover, the cost of living in neighbour countries is much lower. In other words, the purchasing power of 25 euro in Greece corresponds to 12-15 euro in Turkey or Bulgaria. The charge for a hotel room in Greece, due to the high exchange rate of the euro compared to other currencies, is almost double than in Turkey, Egypt, Bulgaria, Romania, Hungary. Even the lowest-paid worker in tourism and agriculture, Greek or immigrant, costs far more, since they get paid in euro, than a worker in some

\footnotetext{
${ }^{4}$ Menandros an ancient Greek philosopher has said that, "loans make slaves the human beings".
} 
other country who gets paid in a devaluated currency. The fact that, Bulgaria belongs to the EU but not to the euro zone and has its own devaluated currency with a very friendly tax system, has led many thousands of Greek companies to transfer there. Greek pensioners are also moving to Bulgaria, because their extremely low pension in euro has an increased purchasing power there. Numerous Greek consumers who reside near the borders with Albania, FYROM, Bulgaria and Turkey go on one-day trips to these countries to buy low-cost products of any kind. As Simon Johnson (2015) points out, the underlying problem in the euro area is the exchange rate system itself - the fact that "these euro zone countries locked themselves into an initial exchange rate, i.e., the relative price of their currencies, and promised never to change that exchange rate. This amounted to a very big bet that their economies would converge in productivity - that the Greeks (and others in what we now call the "periphery") would, in effect, become more like the Germans".

\section{The extreme policies of the Eurogroup}

Every year, successive Greek governments, the European Commission, the IMF, announce optimistic forecasts for the future trends of the Greek economy. These forecasts, also called as "the success story", are always refuted in the end. The IMF accepted that it was wrong with its initial predictions concerning mainly the country's multiplier (I.M.F., 2013, Spiegel \& Harding, 2013, Blanchar, 2015). Yet, the lesson was not learned. Under Berlin guidelines, the euro zone decision makers insist in the same policy of catastrophe. The Eurogroup session of 15 June 2017 concluded with the following monstrous decision that was mostly hidden from the wider public.

"The Eurogroup welcomes the commitment of Greece to maintain a primary surplus of $3.5 \%$ of GDP until 2023 and thereafter a fiscal trajectory that is consistent with its commitments under the European fiscal framework, which would be achieved according to the analysis of the European Commission with a primary surplus of equal to or above but close to $2 \%$ of GDP in the period from 2023 to 2060. The Eurogroup concluded that debt sustainability should be attained within the framework of the debt measures envisaged by the Eurogroup in May 2016. In this regard, the Eurogroup recalled the assessment of debt sustainability with reference to the agreed benchmarks for gross financing needs: GFN should remain below $15 \%$ of GDP in the medium term and below 20\% of GDP thereafter to ensure that debt remains on a sustained downward path».

The debt trap was thus completed, and the country is seemingly held under a modern economic occupation for the next 43 years. With this Eurogroup decision, (which was a prerequisite for a necessary new loan of 8 billion euro for the payment of precious loans), Greece has been obliged to present a yearly budget surplus of 3,5\% (6 billion euro) paid to the lenders. Overall, it should pay 15\% (27 billion) of its GDP up to year 2023 and 20\% (36 billion) up to 2060. It is obvious that, such huge loan liabilities are impossible to be met not only by a destroyed economy such as 
that of Greece but even by prosperous states like Sweeden, Germany, Canada etc. Since this is out of discussion, it appears that the lenders' plan B is to acquire part of such funds by the establishment of the Superfand which already functions under their command. In this Superfand all state property of the country will be included for 99 years ${ }^{5}$. The loss of funds from public property to be owned by the Superfand and to be sold, will deprive the Greek state budget from the influx of precious income and thus, new budget deficits will arise.

This combined with the ever more extreme austerity measures policies imposed by the Eurogroup, will lead to further shrinkage of the economic cycle and to deeper recession. It is an undeniable truth that Greece's colossal debt is not sustainable; a fact that is understood even by first year students of economics. This recession spiralling is irreversible and not any illusion of fake optimism can reverse it. Insofar the country is completely controlled by the distorted euro zone with the overvalued euro and harsh recession policy enforced, along with the disease of the fierce modern stock market capital; there is no possibility for the Greek economy to recover from the coma of destruction that has been trapped in. The ever-renewed forecasts for economic recovery are more near to a science fiction scenario. It is hard to believe that the economic downhill of the Greek economy, can miraculously be averted. Because, to put it simply, no such miracles can happen.

\section{The German debts to Greece for war loans and compensations}

On February 23rd1953, the London agreement was signed in to write off the huge German debt resulting from the two world wars. Some 70 countries had claims against Germany both before the war, and the post war period. The conventional total debt of Germany, pre-war and post-war without counting the war reparations and compensation, amounted to 38.8 billion marks. In accordance with the London Agreement, this debt was deleted by $62.6 \%$ and the repayment of the remaining scheduled to be paid in 10 to 30 years, with an interest rate of $0 \%-5 \%$. The first five years, starting in 1953, the debt would be paid without interest and debt payments should not exceed $5 \%$ of Germany's income from exports.

Thus, Germany was required to repay the rest of the debt, while maintaining a level of development to meet its obligations and to concurrently improve the standard of living of its people. In addition, if the fulfilment of these conditions exceeded its true potential, it would be reconsidered with individual negotiations. With these arrangements, the repayment of German debt (estimated to about $600 \%$ of the GDP), made possible much earlier than planned. After full implementation of the plan in 1958, the debt fell to 6\% of GDP and in 1960 Germany was exempted from

\footnotetext{
${ }^{5}$ The Superfand named "Greek Company of Partnership and Estate" basically controlled by the lenders, acquires for 99 years all state property such as ports, air ports, state land, buildings, hotels touristic real estate, state companies of electricity, petroleum, gas, water, civil transport, railways etc.
} 
amortization obligations. The London Agreement was modelled under sound debt settlement logic and became a reference point for the poor and heavily indebted countries. Greece, which took part in the London Agreement did not collect war loans and reparations from four years of harsh occupation by German troops during the years 1940 to 1945 , which resulted in hundreds of thousands of deaths and huge logistical disasters.

Today, these remedies-compensation, are estimated by the Bank of Greece at 108.43 billion euro, without interest. The occupation loan, amounting to 3.5 billion dollars, is estimated at 54 billion euro, without interest. In accordance with other estimates, these amounts are much larger, even higher than 160 billion euro in current prices. As foreseen in the agreement, part of the debt and war compensations would be paid to Greece with the reunification of Eastern and Western Germany. When the German Union integrated into a single state in 1990, the conference agreed by the London Agreement on this issue, never took place. Germany considered and considers that, an agreement on the reunification has no legal status Peace Treaty; it paid only some minimal compensation of 70 million to war victims that claimed the matter in international courts and hurried to close the matter. Since then, Germany has steadfastly refused to reopen this can of worms. The German government argued that, any plausible bill would exceed the country's resources, and that continued financial co-operation in Europe instead would be infinitely preferable.

Professor Albert Ritschl of the London School of Economics in an outspoken interview to Spiegel ${ }^{6}$ points out that "Germany is king when it comes to debt. Calculated based on the amount of losses compared to economic performance, Germany was the biggest debt transgressor of the 20th century. In the 20th century, Germany started two world wars, the second of which was conducted as a war of annihilation and extermination, and subsequently its enemies waived its reparations payments completely or to a considerable extent. No one in Greece has forgotten that Germany owes its economic prosperity to the grace of other nations. The German bankruptcies in the last century show that the sensible thing to do now would be to have a real reduction of the debt. Anyone who has lent money to Greece would then have to give up a considerable part of what they were owed. Some banks would not be able to cope with that, so there would have to be new aid programs. For Germany, this could be expensive, but we will have to pay either way. At least Greece would then have the chance to start over".

Wolfgang Schäuble, the German Minister of the Economy was asked why he insists on imposing very hard economic burdens upon Greece, while Germany refuses to pay its own debts and war compensations derived from two world wars. He answered simply by saying "these where different times".

\footnotetext{
${ }^{6}$ Interview of Albert Ritschl to Yasmin El-Sharif in in Spiegel on line International,21 June 2011 .
} 


\section{The myth of structural reforms}

Dani Rodrik (2015) describes structural reforms as improvements in regulation and institutions to enhance efficiency with which markets operate, reducing transaction costs of market activity, product and service markets: licensing fees and other costs, labour markets: hiring/firing costs, reducing entry barriers, eliminating monopolies, enhancing the role of private sector over government, improved public sector administration, e.g., tax collection, rule of law. According to the OECD, labour market structural reforms include: (i) simplification of dismissal procedures, (ii) increased flexibility in working-time regulations, and (iii) enhancing firms' wagesetting flexibility. Examples of product market structural reforms consist of: (i) privatisation programmes of state-owned enterprises, (ii) stricter competition laws, and (iii) removing barriers to entry in professional services.

A common definition of structural reforms includes the modernization of public administration, the effective management of the wider state, the abolishment of professional labour and market privileges and monopolies, the promotion of innovation, the proper treatment of tax evasion, the widening of tax base, privatization, deregulation and liberalization. A wider interpretation of the term however includes deep cuts in pensions, wage, incomes and labour conditions. The European Commission which strongly supports structural reforms, relates them with a wide range of measures including actions to promote growth and create more jobs, fiscal responsibility, investment and structural reforms and in particular:

- make labour markets more adaptable and responsive;

- liberalize service sectors, boost competition in product and service markets, specific sectors, or improve overall business environment;

- encourage innovation;

- improve the quality of public taxation systems;

- address the challenges of population ageing on the welfare state.

Behind such well written sentences, lies the wider interpretation of the term, pointing toward pension and wage cuts, as well as including the abolishment of basic labour conditions. The neoliberals insist that, structural reforms tackle obstacles to the fundamental drivers of growth by liberalising labour, product and service markets, thereby encouraging job creation and investment, improving productivity, boosting the economy's competitiveness, growth potential and adjustment capacity. The euro zone supporters are in love with this hypothesis. They insist with passion that; structural reform is the only key to growth and prosperity. So, Greece must inherit this lonesome road to jump out of the crisis.

Every program imposed upon the Greek economy by its creditors since the financial crisis in 2008 has been held together by a central conceit: that structural reforms, conceived boldly and implemented without slippage, would bring about rapid 
economic recovery. The European Commission, the European Central Bank, the International Monetary Fund, all anticipated that fiscal austerity and structural reforms would result in a compensatory boost to the Greek economy. For the last eight years, Greece has been a very good pupil indeed. Successive Greek Governments inherited the deepest the wildest structural reforms in comparison with other European countries together with extreme recessionary economic policies. As a result, from 2010 to 2015 , Greece climbed nearly 40 places in the World Banks's business-environment rankings. Its responsiveness to structural reforms recommendations remains highest amongst other euro zone members (see Histogram V). Despite this, the country's debt is still unsustainably high, with the economy being deeply sick up to present days. Strict monetary and austerity policies and structural reforms implemented until now have succeeded to practically nothing. They transformed a rather wealthy country to a poor state and created immense pain for the people. The Modern Greek Tragedy appears to have no end.

\section{Histogram 5. Change in OECD responsiveness to structural reforms recommendations}

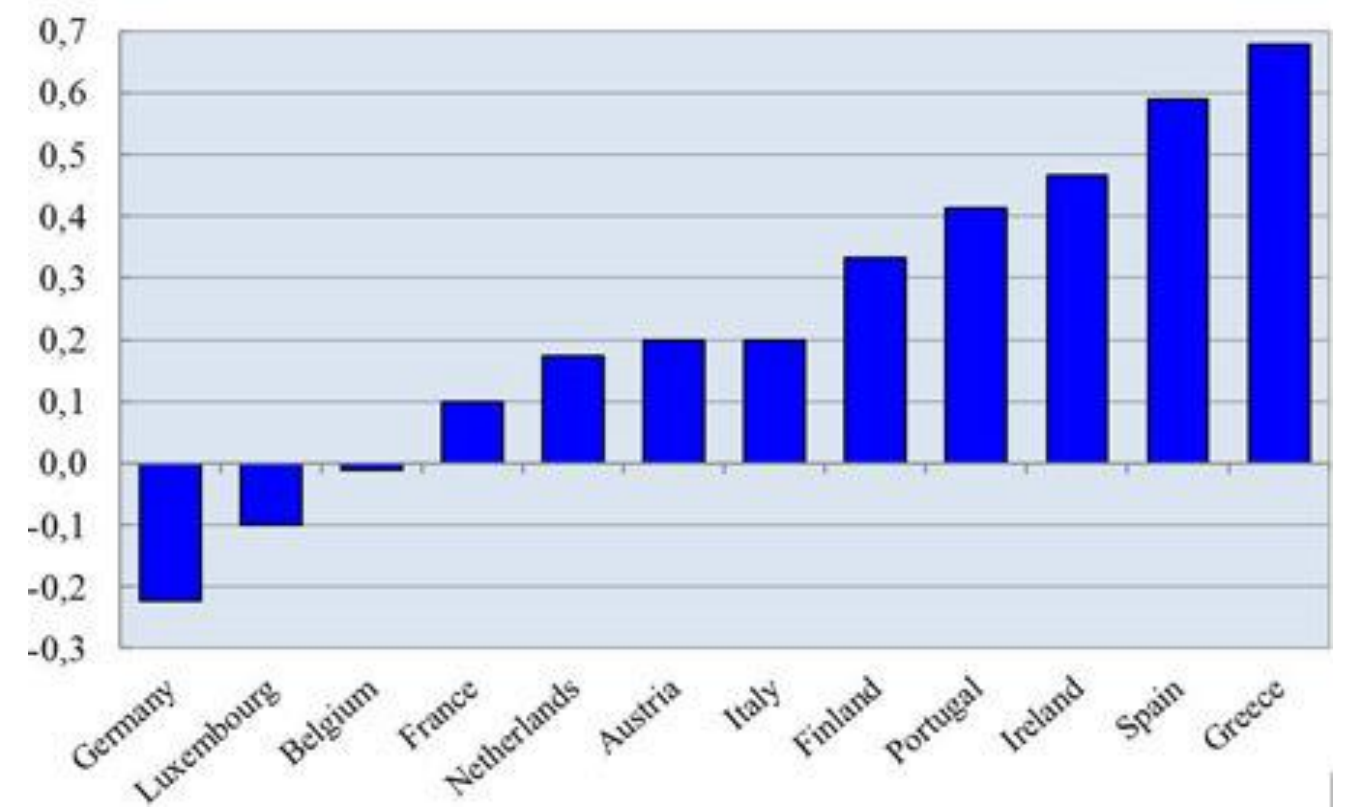

Source: OECD and David Pothier, (2014)

Several studies concerning the outcome of implementing structural reforms around the world-particularly in Latin America and Eastern Europe since 1990-have shown very poor results. It has been found that, privatization, deregulation and liberalization typically produce growth in the longer term at best a little over $1 \%$ (Bouis and Duval, OECD; Buis, et al. 2012). In the short-run, effects are often negative especially when slack in the economy is large. Anderson et al. (2014) has found that, weak demand conditions could dampen the short-run impact of structural reform, and in some cases, structural reforms initiated in weaker initial demand 
conditions have very little positive and possibly negative impact on growth and employment even in the medium run (Anderson et al., 2013).

Moreover, Eggertsson et al. (2014) show that, structural reform does not increase output during a crisis. Their simulation also shows that structural reform may have negative impact when strict monetary policies are active. Anna Rose et al., in an International Monetary Fund research paper ascertain that "Some structural reforms may not achieve the desired improvements, having small or even negative effects in depressed economies. By reducing the uncertainty and sustaining aggregate demand during the reform episode, supportive macroeconomic policies can increase the positive effects of reforms on macroeconomic outcomes. This supports the view that some structural reforms are best initiated in conjunction with supportive fiscal or monetary policy if policy space is available" (Rose, A., Bordon, A., Ebeke, Ch. and Shirono, K. 2016).

Out of many researchers that have searched the impact of structural reforms, only Hobza and Mourre (2010) support that structural reforms could boost real GDP growth from 1.7 percent to 2.2 percent between 2010 and 2020, depending on the depth of the reforms. Yet even if we accept their findings, one wonders if this rate of growth is enough to pull out of the crisis a destroyed economy such as that of Greece.

As Paul Krugman (2013) put it, "such policies are nothing more than a red herring distracting policymakers from the real underlying cause of the Eurozone's economic

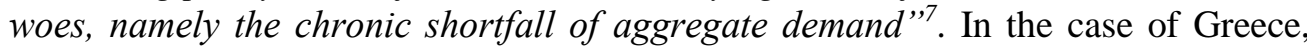
restricted monetary policies together with structural reforms imposed has been a total failure. The statistics, the numbers, the reality, the whole picture speak for themselves. Overall, we may accept that, certain structural reforms such as the rationalization of public administration the combat of tax evasion and corruption, the promotion of innovation are no doubt necessary for the country's progress. But even with the most successful of such reforms, the country will not survive under the siege of a debt trap, extreme austerity policies and an overvalued euro.

\section{Conclusion: The way out}

In front of the deadlock, the only solution appears to be a structured and friendly Grexit, accompanied by a controlled bankruptcy, suspension of debt payments (as

\footnotetext{
${ }^{7}$ Paul Krugman adds to that by saying "OK, let's be clear: I'm in favor of structural reform (as long as it's the right kind of reform). I'm also in favor of peace, kindness, and good coffee for everyone. But when I see influential people calling for structural reform as the universal answer to all economic problems, I get angry. Hence my morning ire at the OECD”.
} 
best illustrated by German loans in the London 1953 Agreement), and negotiations for cutting the debt and extending its repayment period. Structural reforms should concentrate in improving state management, eliminate corruption and tax evasion and reorganizing the social security system on a logical basis. During the initial negotiation days, the government must be ready to provide liquidity to the economy through the issuing of non-interest state bonds at a ratio of 1:1 in relation to the euro (Bootle, 2012). Existing capital controls and the recent widespread transactions with electronic money through the banks, will be helpful for the same cause. Being able to immediately provide liquidity to the Greek economy is crucial for affective bargaining with the lenders, who could not extort deals by threatening to halt the supply of money, as they currently do.

Yet, Greece should not recklessly raise its demands and expectations, ignoring the lenders' geopolitical predominance. To say the least, at such negotiations Greece will not be held at gunpoint. But it must not overvalue its own position. The next step is the issuing of the new drachma devaluated at $25 \%$ in relation to the euro, as a necessary precondition for regaining the lost competitiveness of the economy Thus, one drachma will equal 0,75 euro. The euro may continue to be used as a parallel currency for a period decided in accordance with the result of negotiations and economic trends. In practice, the existence of a parallel currency is today a common practice in many countries worldwide and in Europe as well. Following this initial period, which may last less than a year, it is expected that the economy will regain its lost competitiveness and move towards growth. The annual growth of GDP, wages, pensions and income in general may reach 5-7\%, a soaring increase in employment will create over 1.4 million job positions, and unemployment can recede below $10 \%$.

Care should be taken to avoid hyperinflation which constitutes the main, if not the only risk of transitioning. Today, less than $50 \%$ of the economy's productive capacity is been used and inflation moves at a negative pace. This leads to artificial growth of the loan payments and creates conditions of extreme recession. Therefore, a controlled heating of the economy is needed, if it will not lead to extreme and not easy to control conditions (Katsinos and Mariolis, 2012; Chionis, 2015). In any case, the dangers of hyperinflation may be avoided if the amount of new drachma produced will not exceed a certain level of the M2 of no more than $20-30 \%$ of the GDP (36-54 million euro). Moreover, increases in wages, pensions and incomes in general, may follow and not proceed the GDP growth. So, under the above policies guidelines and considering that imports constitute about $25 \%$ of the country's GDP, we have estimated that, inflation shall be sustained below $8-10 \%$ during the initial stage and afterwards, may fall below 6\% (Katsanevas, 2016).

There shall be no issue of goods sufficiency regarding basic necessities, such as food, medicines, raw materials or fuels, a fact that is further guaranteed by the current surplus in the balance of payments. Banks shall be recapitalized using national currency under state control. Bank deposits and debts in euro will be 
protected through their conversion to new drachmas, at a dr/euro rate 1:0,75, hence covering the devaluation of the new drachma by $25 \%$.

This basically means that a 75.000euro deposit will equal 100.000 new drachmas and so on. Regarding mortgage loans, special provision should be taken under a main policy umbrella and in accordance with cases. Tactical bad debtors who, on a regular basis deliberately avoid making payments upon their loans, shall be subject to legal proceedings. Low and medium incomes may be increased eventually, in relation with labor productivity and GDP growth trends. Government spending restrictions, the combat of corruption, impunity, bureaucracy, tax evasion and the strengthening of productive investments, are also necessary. The Greek economy must be cleared from the pathetic syndrome of the "import country" that depends upon loans, reactivate its production basis, try to consume no more than it produces, abolish malpractices of the past and make a healthy new beginning towards the future.

Among other measures, there is a need to upgrade the national healthcare and welfare system, the enhancement of families with three or more children, the employment of the young and of redundant middle-aged employees. Emerging technologies, modern antagonist industry, pharmaceutical and medical industry and services, internationalization of Greek Universities, shipyards, agriculture and livestock raising should be promoted as major development pillars. Greek ancient heritage, culture, music, theatre and arts in general, should be supported. Research and innovation should be also strongly encouraged, as well as quality tourism, predominantly quality and maritime tourism. Incentives will be offered for attracting Greek shipping owners to be registered under the Greek flag and transferring their registered office in Piraeus.

After eight years of destruction, it has become obvious that the debt trap coupled with the overvalued euro, with austerity policies imposed by the euro zone, is financially sliding down the chasm of catastrophe, with no hope of recovery. A friendly Grexit as was briefly described above, with a generous cut of the county's debt, together with development policies and reasonable structural reforms, is the only applicable way out of this tragedy.

\section{References:}

Anderson, Derek, Ben Hunt, and Stephen Snudden, 2014. Fiscal Consolidation in the Euro Area: How Much Can Structural Reforms Ease the Pain? IMF Working Paper. No. 13/211, International Monetary Fund.

Bevan, J. 2012. Everything you wanted to know about the Greek bailout. http://www.room151.co.uk/blogs

Bouis, R., Orsetta, C., Lilas, D., Romain. D., Aleksandra, Z. 2012. How Quickly Does Structural Reform Pay Off? IZA Journal of Labor Policy, 1:12.

Charalampakis, E. 2017. Effects of the crisis upon the Greek households. Eco-bulletin, Bank of Greece, No 45. www.bankofgreece.gr/Pages/el/Publications/EcoBulletin 
Chionis, D. 2015. Reform and growth or growth and reform. ICABE.

Deo, S., Donovan, P. \& Hatheway, L. 2011. A brief history of breakups. UBS investment research.

Blanchard, O. 2015. Greece: Past critiques and the path forward. IMF.

Bootle, R. 2012. Leaving the Euro: A Practical Guide. Capital Economics, A submission for the Wolfson Economics Prize MMXII.

Eggertsson, G., Ferrero, A. and Raffo, A. 2014. Can Structural Reforms Help Europe? Journal of Monetary Economics, Vol. 61, 2-22.

Hobza, A. and Mourre, G. 2010. Quantifying the Potential Macroeconomic Effects of the Europe 2020 Strategy: Stylized Scenarios. ECFIN Economic Papers 424.

International Monetary Fund. 2013. Greece: Ex Post Evaluation of Exceptional Access under the 2010 Stand-By Arrangement.

International Monetary Fund. 2016. Economic Outlook.

Johnson, S. 2015. The end of the Europe is not about austerity. The New York Times.

Katsanevas, Th. 2014. Greece and the Eurozone Crisis. ICABE.

Katsanevas, Th. 2016. The Modern Greek Tragedy and the Necessary Grexit. Lambert Academic Publications, Berlin.

Katsinos, A., Mariolis, Th. 2012. Switch to devalued drachma and cost push inflation. Modern Economy, 3(2), 164-170.

Klein, N. 2009. The Shock Doctrine: The Rise of Disaster Capitalism. Metropolitan Books.

Krugman, P. 2012. End this Depression Now. Melrose Road Partners.

Negreponti-Delivani, M. 2014). The killing of Greece. Ianos and L' Harmattan.

Pichards, J. 2012. Currency wars. The making of the next global crisis. Amazon.

Sinn, H.W. 2013. Greece should exit the Eurozone as soon as possible and be offered a return ticket! Open Europe, http://klauskastner.blogspot.gr/

Pothier, D. 2014. Structural reforms in the eurozone. DIW Round up, Politics in Focus.

Ritschl, Albert interview to Yasmin El-Sharif in in Spiegel on line International, 21 June 2011.

Rocholl, A. and Stahmer, A. 2016. Where did the bailout money go? The European School of management.

Rodrick, D. 2015a. The elusive promise of structural reforms https://www.projectsyndicate.org/./greece-structural-reforms.

Rodrick, D. 2015b. Structural reforms and Greece : Lessons from other countries. Athens, www.inerpost.gr.

Rogoff, K. 2015). The Modern Greek Tragedy. VOX CEPS Policy portal.

Rose - Bordon, A., Ebeke, Ch. and Shirono, K. 2016. When Do Structural Reforms Work? On the Role of the Business Cycle and Macroeconomic Policies. International Monetary Fund working paper.

Spiegel, P., Harding, R. 2013. IMF admits to errors in international bailout of Greece. Financial Times, http://www.ft.com/intl/cms

Thalassinos, I.E. 2008. Trends and Developments in the European Financial Sector. European Financial and Accounting Journal, 3(3), 44-61.

Thalassinos, I.E., Stamatopoulos, D.T. and Thalassinos, E.P. 2015. The European Sovereign Debt Crisis and the Role of Credit Swaps. Chapter book in The WSPC Handbook of Futures Markets (eds) W. T. Ziemba and A.G. Malliaris, in memory of Late Milton Miller (Nobel 1990) World Scientific Handbook in Financial Economic Series Vol. 5, Chapter 20, pp. 605-639, ISBN: 978-981-4566-91-9, (doi: 10.1142/9789814566926_0020).

Thalassinos, I.E. and Dafnos, G. 2015. EMU and the process of European integration: 
Southern Europe's economic challenges and the need for revisiting EMU's institutional framework. Chapter book in Societies in Transition: Economic, Political and Security Transformations in Contemporary Europe, 15-37, Springer International Publishing, DOI: 10.1007/978-3-319-13814-5_2.

Thalassinos, I.E., Liapis, K. and Thalassinos, E.J. 2014. The role of the rating companies in the recent financial crisis in the Balkan and black sea area. Chapter book in Economic Crisis in Europe and the Balkans, 79-115, Contributions to Economics, Springer International Publishing, DOI: 10.1007/978-3-319-00494-5-6.

Thalassinos, I.E., Deceanu, L. and Pintea, M. 2010. New Dimensions of Country Risk in the Context of the Current Crisis: A Case Study for Romania and Greece. European Research Studies Journal, 13(3), 225-236.

Thalassinos, I.E., \& Stamatopoulos, V.T. 2015. The Trilemma and the Eurozone: A PreAnnounced Tragedy of the Hellenic Debt Crisis. Journal of Economics and Business Administration, 3(3), 27-40.

Thalassinos, E.P. 2014. Credit Default Swaps and Sovereign Debt in Eurozone. Chapter book in Risk Management: Strategies for Economic Development and Challenges in the Financial System, (eds), D. Milos Sprcic, Nova Publishers, 255-278, ISBN: 978163321539-9; 978-163321496-5.

Weeks, J. 2013. Join the euro. Yes, for lower growth.www.socialeurope.eu 